\title{
環境污染と生活環境 \\ Pollution and our Living Environment
}

有 賀 喜 一*

わが国における環境問題は, 昭和30年を契機として 経済の高度成長とともに発生した。昭和33年に水質保 全法及び工場排水規制法が，昭和37年にはばい煙の排 出の規制等に関する法律が制定されたが，期待された 効果が得られないまま，国民の生活水準の向上と相俟 って，環境の悪化，公害の深刻化を一層誘起した．昭 和42年には公害対策基本法が，昭和43年には大気污染 防止法，昭和45年には水質污濁防止法等の関係法令が 制定され，それ以後，環境污染は少しづつ回復の兆を みせてきた。

最近では，国民の生活環境に対する考え方も多様化 した中で，快適な環境を求める声も多くなり，生活環 境をめぐる公害や自然環境の問題一一例えば，生活雑 排水, 一般廃棄物, 近隣騒音等について, 高い関心が 払われるようになってきた。

国民の環境問題に対する現状認識, 被害感, 対応, 要望等についての調查が実施され，公害に関する世論 調查 $^{1)}$ として発表されている. 昭和59年度の調査によ ると，わが国の公害や自然環境に対する評価は，10年 前と比べて「良くなった」と $37.4 \%$ の人が評価してい る. 一方,「悪くなった」と評価した人は 4 人に 1 人の 割合で25.3\%であった．また，10年後のわが国の生活 環境については,「良くなる」23.5\%,「悪くなる」 28.6 \%と悪くなると予測する人がやや多い結果となってい る.

昨年 8 月, 「湖沼環境の保全と管理一人之湖の共存 の道をさぐる」と題するテーマで84世界湖沼環境会 議が滋賀県琵琶湖畔で開催されたのを機会に，「湖をみ んなで美しくする環境展」に参加した人を対象に，公 害に関するアンケート調查 ${ }^{21}$ を日本環境技術協会で実 施した。その調査によると，わが国の公害や自然環境 に対する評価は, 先に実施した世論調查と差のある結 果となったので，その概要について述べる.

アンケート調査では, (1)居住地域周辺の自然環境, (2)生活環境におりる問題，(3)環境を守るための行動,

* (侏)堀場製作所 技術本部副本部長

Kiichi ARIGA
(4)わが国の公害や自然環境に対する評価等について設 問した。

それによると，(1)居住地域における自然環境の状況 を，附近に流れる川の污れ具合と魚の生息状況で調べ た結果では，農山漁村地域では他に比へで川や湖沼は 清浄で魚が生息している所が多いてと，また回答を得 た約80\%の所で環境が悪くても魚が生息するてとがわ かった。(2)居住地域の公害や自然環境を守る上で問題 之な万事項は，(1)「水質の污濁」34.4\%，(2)「でみ処理」 13.5\%，(3)「大気の污染」12.8\%，(4)「すぐれた自然の 景観の減少」 $11.8 \%$ ，(5「騒音」9.6\%の順之なった。 また，乙れを居住地域別にみると，住宅地域では(1)(3) (4)(2), 商店や事務所の多い地域では(1)(3)(5)(2), 農山漁 村地域では(1)(2)(4)(3)の順之なって, 地域によって問題 点の異なることもわかった。(3)家庭で発生する生活雑 排水について日頃から環境污染につながらないよう気を つけているかとの問いに対しては,「一応気をつけている」 60.5\%,「非常に気をつけている」18.9\%，「あまり気を つけていない」14.9\%,「まったく気をつけていない」1.6 \%で, 約 $80 \%$ の人が生活雑排水に対して何らかの気くば りをしているてとがわかった。 (4)わが国 の生活環境 (公 害や自然環境)の評価では, 10年前, 現在, 10年後の状 況について設問した所, 10 年前の生活環境については 「良かった」37.8\%，「悪かった」41.5\%となり，悪 かったと回答した人が多かった. また, 現在の状況に ついては「悪い」と回答した人が断然多く73\%を占め た. 更に 10 年後の状況については $28.8 \%$ の人が良く

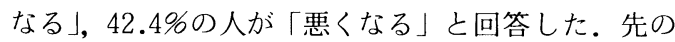
世論調查では，現在の生活環境よりも10年後は，「良く なる」23.5\%,「悪くなる」28.6\%であったあのが，今 回のアンケート調查では「良くなる」 $28.8 \%$ ，「悪くな る」 $42.4 \%$ となって,データの上では, 10 年後の生活環 境は現在よりも「悪くなる」と回答した人が多かった。

今回のアンケート調查で得られた地域住民の公害や 自然環境についての考え方は，概ね次のようである。

(i)一部の地域に扔いては, 今後地域開発が進み, 自 然環境が破壊されるという被害感や危惧の念がある. 


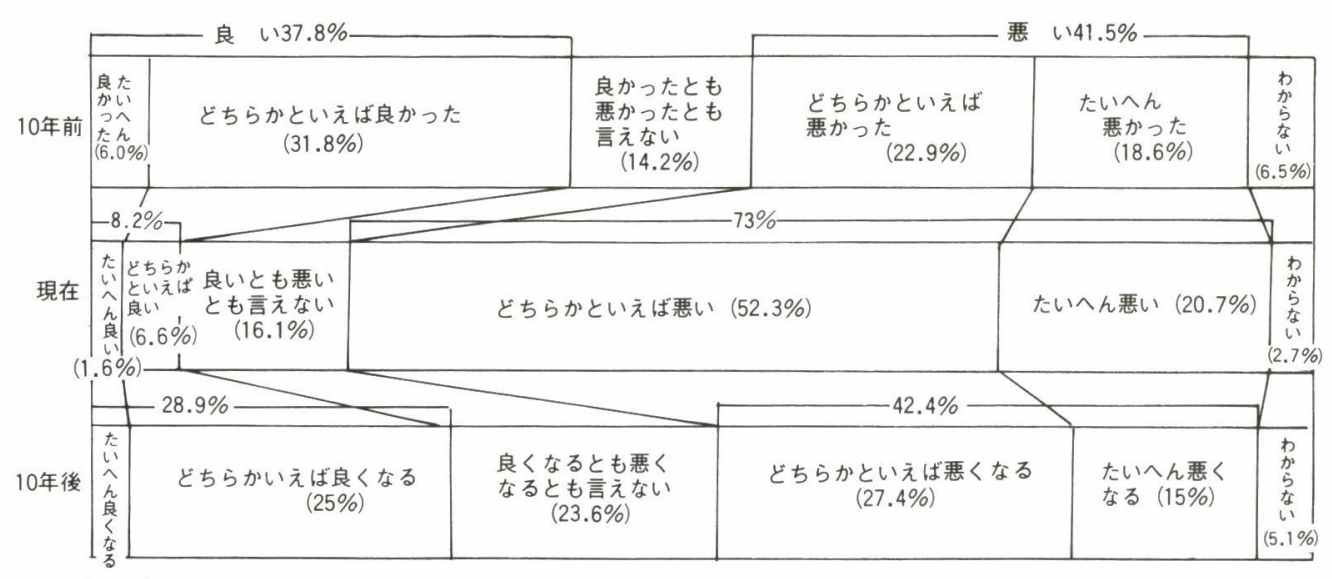

$(3.9 \%)$

図-1 わが国の生活環境の状況10年前, 兒在, 10年後

(ii)大多数の家庭では家族が公害に対する認識を持ち, それぞれの立場で気くばりしながら, 生活環境を快適 なものにしょうと行動している.

(iii) 10 年後には, 現在の生活環境よりもより快適な生 活環境が実現すると 4 人に 1 人は予測し, 一方, 3 割 から 4 割の人は依然として生活環境は悪いと予測して いる.

\section{新製品

酸ソーダポンプ}

ミルフロー製御容量ポンプ

日機装

次亜塩素酸ソーダは不安定な液体で, 放置したまま の状態でも夜中よりガスが分離し, ポンプ停止中や間 欠運転になると接液部内にガスが充満し, 再起動時の 吐出不良という不都合が生じやすく, 特に吐出量の少 ない低ストローク長, 低回転数の上きに顕著であった。 日機装が今回開発した次亜塩素酸ソーダポンプは, 吸 込口を上方に，吐出口を下方に設け，かつガス抜きを 真上に設けて, ガスがポンプ内部へ浸入するととなく 上方へ排出し, 接液部本体へのガスの浸入を効果的に 防止できるようになった。 また，ポンプ停止中接液部 内にガスが発生した場合に, バルブ比重が取扱液比重 より小さいものを使用しているので, ガスが上昇し吸 込バルブ近くに集まり，吸込バルブがガスで被われる とバルブが落下し, ガスと液との置換が行われ, 早期 排出が可能となった。

安定, 高精度注入の

$$
\text { 次亜塩素酸ソーダポンプ }
$$

今回のアンケート調査が, 今後の環境行政の施策の 上で何らかのお役に立つならば幸甚である.

\section{参考 文 献}

1 ) 内閣総理大臣官房公報室：公害に関する世論調査, 昭和 59 年 10 月

2）日本環境技術協会：環技協二ュース，5，(4)，4（1984）

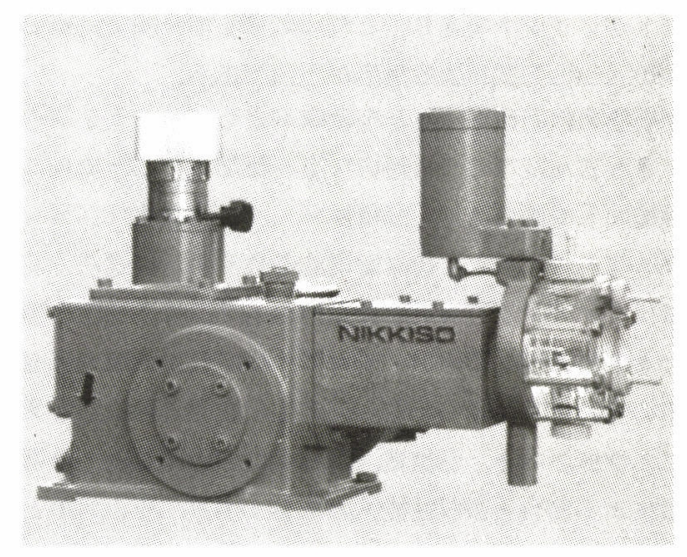

更に, 従来のダイアフラムは発生ガスが透過しやす く, ガスが油圧室に溜まり, 吐出不良を起こすことが あったが, 数百分の一という透過率の特殊ダイアフラ ム使用により, 吐出不良もほぼ完壁に近く防止できる ようになった。

問い合せ先 $=$ 日機装株式会社 東京（03）442-8311 